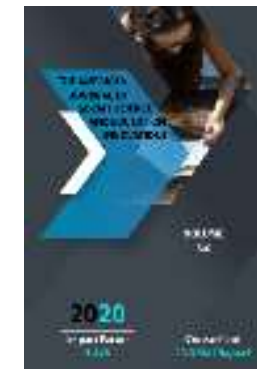

Journal Website: http://usajournalshub.c om/index,php/tajssei

Copyright: Original content from this work may be used under the terms of the creative commons attributes 4.0 licence.

\section{The Role Of Diasporas In The Development Of Cooperation And Friendly Relations Of The Republic Of Uzbekistan With Foreign Countries}

\author{
Baxromjon Xaynazarov \\ Associate Professor, PhD Of The Department Of World History National University Of \\ Uzbekistan Named After Mirzo Ulugbek, Uzbekistan \\ Ahrorqul Hasanovich Pardaev \\ Associate Professor Of The Department Of History And Teaching Methods Candidate Of \\ Historical Science, Jizzakh State Pedagogical Institute, Uzbekistan
}

\title{
ABSTRACT
}

This article clarifies the role of the German, Russian and Korean diasporas in Uzbekistan, in the development of cooperation and friendly relations of the Republic of Uzbekistan with foreign countries. It is scientifically analyzed that inter-ethnic relations are one of the priorities of the state policy of Uzbekistan, which is an important factor for exchange, cooperation and ensuring social stability. It is emphasized that the presence of harmony in inter-ethnic relations can have a profound impact on the political and economic development of multinational societies, which will allow the diasporas of the Republic of Uzbekistan to fully demonstrate their abilities. It was also noted that the favorable socio-political environment created over the years of independence, and harmony between representatives of different nationalities became one of the greatest achievements of Uzbekistan.

\section{KEYWORDS}

State policy, inter-ethnic relations, social stability, diaspora, rights and freedoms, national cultural centers, representatives of the nation and nationality, peace, harmony.

\section{INTRODUCTION}

Interethnic harmony is a state policy of the Republic of Uzbekistan One of the priorities is a particular region, different nationalities in the country coexistence of representatives, cooperation. This issue is also very important for the Republic of Uzbekistan.

Representatives of many nations and ethnic groups have lived in Uzbekistan since ancient 
times. The existence of harmony in interethnic relations effective influence on the political and economic development of a multinational society reaches. This is the full potential of the diaspora in the Republic of Uzbekistan active in all spheres of society, creating opportunities for them to express themselves serves as a great incentive to participate.

\section{THE MAIN RESULTS AND FINDINGS}

After all, it was created in the country sociopolitical environment, the laws of the rights and freedoms of every citizen and their guarantee in Uzbekistan mutual harmony independence between representatives of different nationalities and ethnic groups living became one of the greatest achievements of the years. The work being done on national cultural centers is worldwide is highly recognized by the community. In 2009 Organization for Security and Co-operation in Europe on Minority Nations Activities of the High Commissioner Knut Vollebaek International Cultural Center get acquainted with. Reading different nationalities, their own cultures seeing the conditions created for development, this experience is different states that it should be extended to other countries as well .The activities of national cultural centers are not limited to the domestic, as well as in foreign relations. Because a particular state in the world's diplomatic relations with various countries and the national culture, which is a social association of representatives of the corresponding diaspora has a positive impact on the sustainable operation of the center. For example, Germany, Germans living in the country in the development of relations with Uzbekistan The issue of the diaspora plays an important role. The fate of this diaspora is up to them the conditions created are of direct interest to the German government as well. A number of meetings have been held on this issue. For example, 1995 in Bonn in November, in May 1997, in Tashkent in June 2010, in Berlin in 2011 conducted. In Uzbekistan on June 20, 2012 the Uzbek-German intergovernmental The fifth meeting of the commission was held, during which he lived in Uzbekistan comprehensive support for ethnic Germans, future cultural Enlightenment development, as well as mutual cultural, scientific, enlightenment and issues such as technical relations were discussed. Germany participated in it government spokesman Christoph Bergner is a diverse resident of the Republic of Uzbekistan focusing on the conditions created for the representatives of the nation, is broad in this regard large-scale work is being carried out, representatives of other nationalities and ethnic groups such as the fact that the Germans also live in harmony mentions the assessment. It was also made as part of the fifth meeting noted that he was satisfied with the work and future tasks reaches As a result of similar work, cooperation in other areas. According to a joint statement of Uzbekistan and Germany, relations have expanded in the cities of Tashkent, Bukhara, Samarkand, Gulistan and Fergana medical and social assistance centers have been established Uzbek-South Korean relations can be attributed to such relations. 31 national cultural center of Representatives of the Korean nation in the territory of Uzbekistan. To them other nations and the development of language, culture and customs as representatives of the people conditions have been created for also the South Korean Embassy. The interregional festival of Korean language and culture is traditionally supported transferred. President 
of the Republic of Korea Park Geun-hye Uzbekistan In a letter of thanks to the President of the Republic of Uzbekistan, he wrote: "your focus on the Korean diaspora has amazed me and deeply made an impression", he said. In turn, Korean culture centers also develop various mutually beneficial relations in Uzbekistan have been making a worthy contribution. With the support of the South Korean Embassy the interregional festival of Korean language and culture is traditionally held. At the initiative of the Association of Korean National Cultural Centers 15 highly qualified doctors from the Republic of Korea were invited in 5 days provided medical care through charity. Tashkent from such assistance citizens of different nationalities living in the city and province enjoy which was. It is also the Russian national culture in relations with the Russian Federation has made a significant contribution to the centers. The Russian national culture centers are national holidays of the Russian people, Russian writers and celebrities anniversaries, May 9 Memorial and Remembrance Day, celebrated June 12 "Russia Day" holidays and other events of the Russian Federation Embassy of the Republic of Uzbekistan in cooperation with Roszarubejtsentr is formed. Today, national cultural centers are not just their own national culture preservation, preservation of culture, but also brought to the Republic of Uzbekistan ongoing socio-economic and cultural reforms became one of the active participants. In particular, agriculture, private activities of people in the fields of entrepreneurship, culture and sports, achieved His achievements are being disseminated to the public and the younger generation. Under the centers announced by the Republic through various meetings opened government programs, social reforms and other changes affect the nation and is widely promoted among the population and is active in these updates is participating. Such work is primarily accepted in the Republic of Uzbekistan support government programs among all segments of the population each of these programs by the centers again, if it shows that it is supported means it helps to cover a family. Five of the development of the Republic of Uzbekistan in 2017-2021 Adoption and implementation of the Priority Action Strategy human values in the minds of the population, especially young people, to further strengthen mutual understanding between the representatives of the two nations; to raise the work carried out in the council to a qualitatively new level demanded. Therefore, on May 19, 2017, the President of the Republic of Uzbekistan "Interethnic relations and friendship with foreign countries On measures to further improve relations " the decree was adopted. This decree guarantees the stability of civil harmony, ensuring peace and harmony between different nationalities, strengthening the sense of a multi-ethnic single family, national cultural centers and comprehensive support for the activities of friendship societies and more development of cultural and educational ties with foreign countries Republican International Cultural Center and Friendship for the purpose of expansion Cabinet of Ministers of the Republic of Uzbekistan on the basis of the Center interethnic relations and friendship with foreign countries Aliaison committee was set up. This Committee is responsible for interethnic harmony and tolerance in society ensuring peace-loving policies in all spheres of life in the country wide dissemination of achievements and successes, the international 
community, including strengthening friendships with the Uzbek diaspora abroad the task of consistent implementation of state policy on .

\section{CONCLUSION}

"Interethnic relations and friendship with foreign countries. On measures to further improve relations youth tolerance, respect for national and universal values, history, to cultivate in the spirit of preservation of culture, national traditions and customs special attention is paid. This is nationalism and extremism in turn has ideological immunity against his beliefs, is committed to the ideas of independence, Protecting and promoting the national interests of Uzbekistan allows the formation of a spiritually harmonious generation. Such tasks are undoubtedly interethnic and inter-religious in Uzbekistan an integrated system to ensure harmony, peace and stability development, more convenient and extensive opportunities for national cultural centers create, support their initiatives and aspirations, activities raising to a new level in terms of quality, friendship with foreign countries and policies aimed at further developing cultural and educational ties leads to a new level.

\section{REFERENCES}

1. Muhammadiev N. Tolerance and Solidarity // People's Speech, 20098 August.

2. Turaev A. Dialog culture // Narodnoe slovo, 2012 god 21 June. - S. 4.

3. Novitskiy V. In one building // Pravda Vostoka, September 21, 2012. -S.3.

4. Pak Kin XE. To the President of the Republic of Uzbekistan, // People's speech, August 22, 2014.
5. Novitskiy V. In one building // Pravda Vostoka, September 21, 2012

6. Shin V. At the new stage of birth // Solidarity and tolerance development factor.Tashkent,2001.P.121.

7. Resolution of the President of the Republic of Uzbekistan dated May 19, 2017 4957- issue "Interethnic relations and friendship with foreign countries Decree "On measures to further improve relations."

8. Decree of the President of the Republic of Uzbekistan dated May 19, 20174957

" Interethnic relations and friendship with foreign countrie Decree "On measures to further improve relations" II

9. Khainazarov, B. (2013). From the history of the Uighurs of the Republic of Uzbekistan. Scientific review: theory and practice., (1), 57.

10. Khainazarov, b. B. (2017). FROM THE HISTORY OF FORMATION OF THE UIGUR DIASPORA IN UZBEKISTAN. Theoretical \& Applied Science, (3), 5155.

11. Rasuljanovna, I. N., \& Rakhmonqulovich, K. N. (2020). Trade Relations Between Ancient Bacteria And China On The II-I BC. The American Journal of Social Science and Education Innovations, 2(07), 47-51.

12. Kariev, A., \& Aminov, H. (2020). New information about Imam al-Zarnūjī and his work "Ta'limm al-Muta'allim”. Solid State Technology, 63(6), 2372-2387. 